\title{
Designing the Online Collaborative Learning Using the Wikispaces
}

\author{
http://dx.doi.org/10.3991/ijet.v7i1.1863
}

\author{
D. Sulisworo \\ Ahmad Dahlan University, Yogyakarta, Indonesia
}

\begin{abstract}
Collaboration has become one of an essential skill necessary for effective functioning in society in the new era. As a consequence, the learning strategy at the higher education should consider this shifting. Web 2.0 technology is a new trend in communication technology that has become a basis of the new generation internet to make it a more mature and distinctive medium of communication. The problem is how to bring the offline learning using cooperative learning based on classroom to the online learning using this wiki. The learning design on this topic will give wide opportunity to access learning that more suitable to the new skill in the new era. Wikispaces is one of wiki facilities that operated in the web based. This wiki is so simple but suitable for collaborative learning. The learning scenario is Jig Saw approach modified to fit in the online collaborative learning environment. This technique, including two different treatments with different small groups in order to help learning and improving cooperation between students. Using this structure, students are responsible for share their skill or knowledge each other material.
\end{abstract}

Index Terms - collaborative, online learning, wiki, Jig Saw.

\section{INTRODUCTION}

During the last two decades the learning environment has experienced an rapid changing driven the information and communication technology. The rapid evolution of information and communication technologies (ICT) and web technologies of recent decades is seeing a shift in the scale and rapid growth of adopters of mobile devices and Web 2.0 technologies. This is evident in newer generations of students enrolled in higher education institutions [1] [2]. Learning and refining on such skills as critical thinking and problem solving, communication, creative thinking, collaboration, leadership, adaptability, and selfdirection is very important for students in this era [1][3]. Collaboration has become one of an essential skill necessary for effective functioning in society. As a consequence, the learning strategy at the higher education should consider this shifting.

Nowadays, internet is used more intensive on learning. Consequently, there is a shift in how students learn and communicate and how the increasing functionality of technologies are raising the bar in learning, employability skills, communication, collaboration, creativity, leadership and information literacies [1][4]. Internet become more effective to be used as learning media especially after the emergence of Web 2.0 as a tool for facilitating collaboration on learning. One of the most popular Web 2.0 technologies is wikis, which have shown much promise in promoting communication, collaborative authoring, and information sharing [3][5][6]. Wikis are characterized by simplicity, accessibility, and interoperability. In recent years education has been undergoing a shift from teachercentered and instruction-based curriculum implementation to student-centered and inquiry-based learning. Students are routinely required to engage in collaborative learning activities such as group projects, presentations, group discussions, and peer evaluations that require significant collaboration and communication with classmates [6][7].

The student skill especially on such skill as critical thinking and problem solving, communication, creative thinking, collaboration, as mention before can be facilitated using the new learning system like wikis [1][3][8][9]. The problem is how to bring the offline learning using cooperative learning based on classroom to the online learning using this wiki. The learning design on this topic will give wide opportunity to access learning that more suitable to the new skill in the new era.

\section{LiTERATURE REVIEW}

\section{A. Web 2.0. and Wiki characteristics}

Ref. [6] describe Web 2.0 technology is a new trend in communication technology that has become a basis of the new generation internet to make it a more mature and distinctive medium of communication by facilitating user to develop web applications interactively and interoperable. Web 2.0 technology refers to the new generation of web development and design concepts that are more organized than its predecessor, Web 1.0 technology. It allows internet users to transition from the static to the dynamic to the dynamic web technologies both in using and developing web applications. Based on the easier access to the internet through computers, cellular, and handheld devices, Web 2.0 tools enable users to develop a collaborative virtual society to share information interactively and interoperable [6][10].

Desilets et al. on Ref. [11] defines wikis as simple to use asynchronous, web based collaborative hypertext authoring systems. Wikis are web pages that people can directly edit, update, modify or delete [9][11][12][13]. Wikis can be likened to a collaborative word processing document allowing multiple users from different locations to collaborate in real-time [13][14]. Wikis allow us to create collaborative knowledge spaces that harbour learning practices that extend beyond the boundaries of traditional formal education [3][9].

Wiki applications are web-based hypertext applications that facilitate collaborative editing and are supported by a mechanism for monitoring the changes and contributions made to the sections edited. Many virtual communities in 


\section{SHORT PAPER}

\section{DESIGNING THE ONLINE COLLABORATIVE LEARNING USING THE WIKISPACES}

various academic and practical areas have adopted wiki applications because of their advantages with regard to knowledge creation, sharing, dissemination, and accumulation [7][11][14][15]. Systems that adopt wiki applications have three essential characteristics which individually and jointly create a robust collaborative environment. These are collectively referred to as wiki characteristics, and are described as follows [11][10][12] [16] [17]:

- Open collaborative authoring (open editing), which refers to the ability for anyone to easily edit the content on a wiki.

- Controlling changes (edit preservation) and security, which refers to the ability to retain and trace all the edits to and versions of content contained on a wiki, and the ability of wiki administrators to choose different privacy settings to determine specifically who can view and edit content on a wiki in order to ensure its quality.

- Linking and creating pages (knowledge structuring), which refers to the ability to group web pages on a wiki that contain different kinds of content into various categories based on their similarity, and the ability to enable users to establish links between pages within a wiki or to external web pages.

The key to the formation of a virtual community is the application of ICTs. Consequently the characteristics of such technologies such as ease of use, flexibility, reliability, and usefulness may affect the intentions of the users to participate in virtual communities, as well as the level and frequency of interpersonal interactions among community members. The use of wiki applications in a learning activity can enable the monitoring and improvement of the interactions between teacher and student. This can then lead to a higher intensity of student participation with teacher and with other student in a collaborative knowledge sharing process [3][6].

\section{B. Collaboration}

Collaboration is sometimes distinguished from cooperative learning in that cooperation is typically accomplished through the division of activity, with each person responsible for some portion of the problem solving [18][19][20]. Collaboration, on the other hand, involves participants working together on the same task, rather than in parallel on separate portions of the task. Collaboration as the "mutual engagement of participants in a coordinated effort to solve a problem together". Collaboration can be seen as "coordinated, synchronous activity that is the result of a continued attempt to construct and maintain a shared conception of a problem". Collaborative interactions are characterized by shared goals, symmetry of structure, and a high degree of negotiation, interactivity, and interdependence. Interactions producing elaborated explanations are particularly valuable for improving student learning. Nonresponsive feedback, on the other hand, can be detrimental to student learning in collaborative situations.

There is an indication that e-learning as well as wiki approach that students need substantial motivation and control in order to achieve their learning goals. The technology involved is not nearly as important as other factors, such as learning tasks, learner characteristics, student motivation and the instructor. Student motivation to involve and to share their knowledge and skill is the very important factor that affect online student learning performance [2][6][21]. Collaboration can have powerful effects on student learning, particularly for low-achieving students. However, a number of factors may moderate the impact of collaboration on student learning, including student characteristics, group composition, and task characteristics.

Collaborative learning refers to tasks that require joint intellectual efforts among students or between students and teachers. In most instances this involves students working in groups to co-construct an artifact (e.g. a report or presentation) for assessment. More specifically, it also involves social interactions as small groups of students solve an academic problem together. As a learning strategy it emphasizes social and intellectual interaction in the learning process such that the differences in knowledge, skills, and attitudes among collaborators become strengths rather than weaknesses. Knowledge is shared and acquired during communication, negotiation, and production of materials. Through collaborative learning, learners have the opportunity to equip themselves with stronger analytical skills for interpreting information and acquiring further knowledge [6][20][22][23]. In return they contribute by co-constructing and sharing knowledge within their learning community. Knowledge construction and sharing are among the processes involved in knowledge management.Interaction is an important component of learning experience for both in conventional education and distance education [24] as well as using wiki.

The challenge on the online collaborative learning is the wide variation in the meaning of words like "online" and "computer supported collaborative learning”. In some studies online groups occasionally gather in face-to-face settings and in other studies the groups are framed as geographically distributed subgroups. Examination of the completely online case is rare. Variations in sociotechnical context are widely understood to have a material effect on group experience, but consideration of these effects is glossed over in much work that examines these different constructions of "online group" [15][25]. This challenge should be considered when group activity used to improve new student skill.

\section{MethodOLOGY}

\section{A. Subject}

One of the subject of Primary School Teacher Training is The used ICT for Learning. This subject is a capstone design subject that need many student skill for instant how to understand the primary school subject, how to arrange a learning strategy, how to conduct the learning assessment and evaluation, and how to share and publish learning program to others. Considering these characteristics, the collaborative learning will fit for student activity.

One of the consequence of the credit semester in the higher education is that the learning duration is 14 weeks in one semester. The learning monitoring should be conducted by teacher each week to ensure student run their activity. Encouraging and motivating student are very important in this learning environment.

\section{B. Wiki Tools}

Wikispaces (http://wikispaces.com) is one of wiki facilities that operated in the web based. This wiki is so simple but suitable for collaborative learning. This is the 
reason why in this design using this wiki. Student are able to literate their skill using this wiki in the short time. The main features in this wiki that used to support collaborative learning are page, discussion, project, and uploading and downloading the document.

Project is the most important feature in this learning scenario. With Projects, teacher can put student who been wiki members into groups so they can work independently. Each Project on wiki is made up of a unique set of teams of members, pages, files, and settings. There's no limit to the number of teams within a Project, or to the number of pages within a team, but here are a few things to keep in mind as you get started:

- Only members of the wiki can be members of a team on that wiki.

- Every team should have at least one member.

- Every team starts out with one page, called "home." Teacher and team members can create more pages as the teamwork continues.

An individual user can only be a member of one team, maximum, within any given Project (although not all wiki members must be assigned to a team for every project on your wiki).

\section{DESIGN RESUlt}

In general, the learning scenario is Jig Saw approach modified to fit in the online collaborative learning environment as mention before. Jigsaw, one of the cooperative learning techniques, is based on group dynamics and social interactions. It is one of the cooperative learning techniques. This technique, including two different treatments with different small groups in order to help learning and improving cooperation between students [19][23]. Using this structure, students are responsible for share their skill or knowledge each other material.

A unit of work, is divided into 5 expert areas, and each student on a team is assigned one area. Experts from different teams meet together at same project page to discuss their expert areas. Students then return to their teams and take turns sharing. A project may be given at this time to solve together. Jig sawing materials refers to any strategy in which each student on a team receives only a piece of the material that is to be learned so that students must rely on the other members of their team to learn all of the material to solve their project.

Using this scenario, teacher should ensure the interaction among student would exist. Collaborative interaction occurs when learners interact among themselves [19][23*]. However, in this wiki tools the collaborative learning activity is facilitated by asynchronous discussion forums.

To manage the activities, we divide to 4 time blocks. The activity and the time duration for each block is shown by table 1 .

\section{DISCUSSION}

Basically, cooperative learning rooted to behaviorism paradigm different to collaborative learning rooted to constructivism. Understanding the principles of constructivism may be an instructive way toapproach effective educational technology design. This learning theory asserts that students construct knowledge from experience.
TABLE I.

LEARNING SCENARIO

\begin{tabular}{|c|c|}
\hline Activity & Output/ Outcome \\
\hline \multicolumn{2}{|c|}{ Block I: Introduction (2 weeks) } \\
\hline Sign up to wiki & Account \\
\hline Create page & One student page \\
\hline Student upload a document & At least 3 document uploaded \\
\hline Posting and Reply discussion & At least 2 posting and 3 replies \\
\hline \multicolumn{2}{|c|}{ Block II: Expert Group Activity } \\
\hline $\begin{array}{l}\text { Teacher assigns student to } \\
\text { expert group }\end{array}$ & $\begin{array}{l}5 \text { expert groups, i.e. i.e. Learn- } \\
\text { ing Strategy Group, Learning } \\
\text { Material Group, Learning } \\
\text { Media Production, Learning } \\
\text { Assessment and Evaluation } \\
\text { Group, Product Socialization to } \\
\text { internet Group }\end{array}$ \\
\hline \multicolumn{2}{|l|}{ Reading the expert materials } \\
\hline $\begin{array}{l}\text { Reply the discussion moder- } \\
\text { ated by teacher }\end{array}$ & $\begin{array}{l}\text { At least } 3 \text { replies, } 5 \text { discussion } \\
\text { topics }\end{array}$ \\
\hline $\begin{array}{l}\text { Teacher asks student to post } \\
\text { some question and reply some } \\
\text { answer for each other }\end{array}$ & $\begin{array}{l}2 \text { question each, and answer for } \\
\text { each question }\end{array}$ \\
\hline $\begin{array}{l}\text { Students upload their product } \\
\text { to each expert page }\end{array}$ & $\begin{array}{l}\text { Uploaded document as a student } \\
\text { product (.doc, .ppt, etc.) }\end{array}$ \\
\hline \multicolumn{2}{|c|}{ Block III: Project Group Activity } \\
\hline \multicolumn{2}{|c|}{\begin{tabular}{l|l} 
Teacher assigns student to the & \\
new group as a project group. & \\
Each group involve 5 student & \\
from different expert &
\end{tabular}} \\
\hline $\begin{array}{l}\text { Each group decide their topic } \\
\text { from primary school subject. } \\
\text { Teacher can guide the topic for } \\
\text { each group }\end{array}$ & $\begin{array}{l}\text { The topic should be continued } \\
\text { from one group to other group } \\
\text { so all student will get the com- } \\
\text { prehensive project result. }\end{array}$ \\
\hline \multicolumn{2}{|l|}{$\begin{array}{l}\text { Accomplishing the project } \\
\text { result draft }\end{array}$} \\
\hline $\begin{array}{l}\text { Review the product by upload } \\
\text { it to the general page that can } \\
\text { be accessed by other group }\end{array}$ & $\begin{array}{l}\text { Comment and response from } \\
\text { other group }\end{array}$ \\
\hline $\begin{array}{l}\text { Refining the draft and publish } \\
\text { the result }\end{array}$ & $\begin{array}{l}\text { Complete primary school } \\
\text { subject }\end{array}$ \\
\hline \multicolumn{2}{|c|}{ Block IV: Project Review } \\
\hline $\begin{array}{l}\text { Each group give some com- } \\
\text { ment to other group to improve } \\
\text { their product draft. Once after } \\
\text { draft published and once after } \\
\text { final product }\end{array}$ & \\
\hline
\end{tabular}

Learning occurs when students undertake "authentic activities" that have real-world relevance and require them to solve ill-defined, multifaceted problems through collaboration. Constructivism "shifts attention from instruction as the imparting of knowledge to instruction as the guidance of socially-based exploration in intellectually rich settings" . Therefore, the learning scenario can facilitate student to more collaborative learning.

In the other benefit of using this scenario, the development of a skill set that matches both views on learning skills (problem solving, collaboration, sharing ideas, focus on learning etc.) and views on employability skills such as communication, collaboration, creativity, leadership and technology proficiency will be done. But there are many factor should be taken to account especially on teacher ability to guide student and student motivation to selfregulated learning.

It would be two challenge when implemented the design. The first, the challenge of community formation in a virtual world that need the mutual engagement and group member commitment. 


\section{SHORT PAPER \\ DESIGNING THE ONLINE COLLABORATIVE LEARNING USING THE WIKISPACES}

Beside the kind of activity chosen by teacher that may enhance the probability that productive interactions occur, the literacy of student on handling the wiki will affect the learning effectiveness. To increase the success possibility of online collaborative learning, student preparation and understanding the Jig Saw technique via Wikipaces should be conduct to ensure the learning process can be well done.

\section{SUMMARY}

From the teacher's perspective, this wiki serve aspotentially effective tools in managing and monitoring students' collaborative groupprojects. The platform gave the teachers the facility to closely monitor studentprogress and provide feedback to assist in the effective management of the learning process. There was no longer any need to ask for drafts of the activity. Instead, comments could be added in learning environment immediately. This researchhas shown that there are benefits for student learning and monitoringand feedback by the teacher using Wiki in the collaborative learning environment..

\section{REFERENCES}

[1] J. Chelliah and E. Clarke. (2011), "Collaborative teaching and learning: overcoming the digital divide?”, On The Horizon, Vol. 19 No. 4, pp. 276-285. http://dx.doi.org/10.1108/107481211 11179402

[2] S. Siritongthaworn and D. Krairit (2006), "Satisfaction in elearning: the context of supplementary instruction”, Campus-Wide Information Systems, Vol. 23 No. 2, pp. 76-91. http://dx.doi.org/ $\underline{10.1108 / 10650740610654465}$

[3] S. Chuand D. Kennedy (2011) "Using online collaborative tools for groups to co-construct knowledge", Online Information Review, Vol. 35 No. 4, pp. 581-597. http://dx.doi.org/10.1108/ 14684521111161945

[4] C. Chen, J. Wu, and S. Yang (2006), "The efficacy of online cooperative learning systems: The perspective of task-technology fit”, Campus-Wide Information Systems, Vol. 23 No. 3, pp. 112127. http://dx.doi.org/10.1108/10650740610674139

[5] J. Zywica, K. Richards. and K. Gomez (2011), “Affordances of a scaffolded-social learning network”, On The Horizon, Vol. 19 No. 1, pp. 33-42. http://dx.doi.org/10.1108/10748121111107690

[6] Md. Hossain and H. Aydin (2011), “A Web 2.0-based collaborativemodel for multicultural education”, Multicultural Education \& Technology Journal, Vol. 5 No. 2, pp. 116-128.

[7] A. Norberg, C. Dziuban and P. Moskal (2011), “A time-based blended learning model”, On The Horizon, Vol. 19 No. 3, pp. 207 216. http://dx.doi.org/10.1108/10748121111163913

[8] C. Greenhow (2011), "ViewpointOnline social networks and learning”, On The Horizon, Vol. 19 No. 1, pp. 4-12. http://dx.doi.org/10.1108/10748121111107663

[9] T. Menkhoff, T. Yian, C. Wah, and W. Kee (2011), Engaging knowledge management learners through web-based ICT: an empirical study", VINE: The journal of information and knowledge management systems, Vol. 41 No. 2, pp. 132-151.

[10] A. Zyl (2009), “ The impact of Social Networking 2.0 on organizations”, The Electronic Library, Vol. 27 No. 6, pp. 906-918. http://dx.doi.org/10.1108/02640470911004020
[11] P. Laughton (2011), "The use of wikis as alternatives to learning content managementsystems, The Electronic Library, Vol. 29 No. 2, pp. 225-235 http://dx.doi.org/10.1108/02640471111125186

[12] W. Wang and Z. Wei (2011), "Knowledge sharing in wiki communities: an empirical study”, Online Information Review, Vol. 35 No. 5, pp. 799-820. http://dx.doi.org/10.1108/146845211111765 $\underline{16}$

[13] J. Frumkin (2005), "Digital Libraries: Modern Practices, Future Visions The Wiki and the digital library”, OCLC Systems \& Services: International Digital Library Perspectives, Vol. 21 No. 1, pp. 18-22.

[14] Y. Liu, H. Chen, C. Liu, C. Lin and H. Chan (2010), “A Model to Evaluate the Effectiveness of Collaborative Online Learning Teams - Self-Disclosure and Social Exchange Theory Perspective", International Journal of Cyber Society and Education, Vol. 3, No. 2, Pages 117-132.

[15] D. Persico and F. Pozzi (2011) , “ Task, Team and Time to structure online collaboration in learning environments”, World Journal on Educational Technology, Vol 3, Issue 1, pp. 01-15.

[16] E. Mason (2008), "Using a wiki to publish a research guide", Library Hi Tech News, Number 9, pp. 17-21. http://dx.doi.org/ $\underline{10.1108 / 07419050810946213}$

[17] H. Keser, H. Uzunboylu and F. Ozdamli (2011), "The trends in technology supported collaborative learning studies in 21st century”, World Journal on EducationalTechnology, Vol 3, issue 2, pp. 103-119.

[18] E. Lai (2011), Collaboration: A Literature Review, PEARSON.

[19] A. Sahin (2010), "Effects of jigsaw II technique on academic achievementand attitudes to written expression course”, Educational Research and Reviews,Vol. 5(12), pp. 777-787.

[20] T. Wasonga (2007), "Using technology to enhance collaborative learning”, International Journal of Educational Management, Vol. 21 No. 7, pp. 585-592. http://dx.doi.org/10.1108/0951354071082 2184

[21] M. Abbad and M. Albarghouthi (2011), “Evaluate Students' Perceptions of the Virtual Learning Environment at Paisley University”, International Journal of Emerging Technologies in Learning, Vol. 6 No.3, pp. 28-34

[22] M. Farajollahi and M. Moenikia (2011), “ The effect of computerbased learning on distance learners' self regulated learning strategies”, World Journal on Educational Technology, Vol 3, Issue 1, pp. 28-38.

[23] N. Dabbagh (2007), "The online learner: Characteristics and pedagogical implications”, Contemporary Issues in Technology and Teacher Education, 7(3), 217- 226.

[24] I. Ismail, R. Idrus, H. Baharum, M. Rosli and A. Ziden(2011), “The Learners' Attitudes towards Using DifferentLearning Methods in E-Learning PortalEnvironment”, International Journal of Emerging Technologies in Learning, Vol. 6 No.3, pp. 49-52

[25] S. Goggins, J. Laffey, and M. Gallagher (2010), “ Completely online group formation and development: small groups as sociotechnical systems”, Information Technology \& People, Vol. 24 No. 2, 2011, pp. 104-133.

\section{AUTHOR}

Dwi Sulisworo is with the Education Management Department, Ahmad Dahlan University, Yogyakarta, Indonesia (e-mail: dwi@uad.ac.id).

Received 7 November 2011. Published as resubmitted by the author 28 February 2012. 